\title{
ВИВЧЕННЯ ВАЛІДАЦІЙНОГО ПАРАМЕТРА “ЛІНІЙНІСТЬ/ КАЛІБРУВАЛЬНА МОДЕЛЬ” АНАЛІТИЧНОЇ МЕТОДИКИ КІЛЬКІСНОГО ВИЗНАЧЕННЯ УРОКАРБУ В ПЛАЗМІ КРОВІ ДЛЯ ПРОВЕДЕННЯ ФАРМАКОКІНЕТИЧНИХ ДОСЛІДЖЕНЬ
}

Вступ. Аналіз публікацій у провідних світових хіміко-аналітичних та фрармацевтичних журналах дозволяє зробити висновок про пріоритетний інтерес дослідників до валідації біоаналітичних методик, на що вказує постійне вивчення валідаційних параметрів, у тому числі параметра "лінійність/калібрувальна модель". Таким чином, набувають актуальності питання, пов'язані з визначенням валідаційного параметра “лінійність/калібрувальна модель", який використовують під час доклінічних фрармакологічних досліджень лікарських засобів та розробки стандартизованих підходів до проведення таких валідаційних робіт для оригінальних субстанцій.

Мета дослідження - провести експериментальне вивчення валідаційного параметра “лінійність/ калібрувальна модель" аналітичної методики кількісного визначення урокарбу в плазмі крові для виконання фрармакокінетичних досліджень.

Методи дослідження. Біоаналітична методика визначення урокарбу ґрунтується на ВЕРХ/MC/MC аналізі аналітів у досліджуваних розчинах, отриманих із зразків плазми після попереднього осадження білків. Проби хроматографрують із використанням хроматографрічної колонки Discovery C18, 50×2,1 мм, 3 розміром часток 5 мкм та градієнтного елюювання.

Результати й обговорення. Придатність біоаналітичної методики була підтверджена валідаційними характеристиками, які висувають до біоаналітичних методик. У цій роботі описано валідаційний параметр “лінійність/калібрувальна модель". Розроблено електронні протоколи з використанням Microsoft Excel, в яких передбачено поля для введення даних. При побудові калібрувальної кривої необхідно виконати такі умови: для нижньої межі кількісного визначення відхилення від номінальної концентрації повинно бути не більшим \pm 20 \%, для калібрувальних розчинів з концентраціями, вищими, ніж нижня межа кількісного визначення, - не більшим $\pm 15 \%$. Доведено лінійну залежність між концентрацією та площею хроматографрічних піків урокарбу в діапазоні концентрацій 1-100 нг/мл. Рівняння регресії - y=0,00365x+0,000177, коефріцієнт кореляції - $r^{2}$ 0,9993.

Висновки. Проведено експериментальне вивчення валідаційного параметра "лінійність/калібрувальна модель" аналітичної методики кількісного визначення урокарбу в плазмі крові для виконання фрармакокінетичних досліджень. Висновок щодо розробленої методики стосовно валідаційного параметра “лінійність/ калібрувальна модель" - коректна.

КЛЮЧОВІ СЛОВА: урокарб; валідація; валідаційний параметр “лінійність/калібрувальна модель”; фармакокінетика.

ВСТУП. Аналіз публікацій у провідних світових хіміко-аналітичних та фрармацевтичних журналах дозволяє зробити висновок про пріоритетний інтерес дослідників до валідації біоаналітичних методик, на що вказує постійне вивчення валідаційних параметрів, у тому числі параметра "лінійність/калібрувальна модель". Таким чином, набувають актуальності питання, пов'язані з визначенням валідаційного параметра "лінійність/калібрувальна модель", який використовують під час доклінічних фрармакологіч(с) І. В. Драпак, 2019. них досліджень лікарських засобів та розробки стандартизованих підходів до проведення таких валідаційних робіт для оригінальних субстанцій [1-11].

Урокарб (N-(5-метил-[1,3,4]тіадіазол-2-іл)пропіонамід) - оригінальний новосинтезований діуретик, який підвищував добовий діурез у білих щурів: порівняно з інтактним контролем - у 2,47 раза і більше ( $\mathrm{p} \leq 0,001)$, порівняно з гідрохлортіазидом - в 1,6 раза, ацетазоламідом - в 1,75 раза [12]. При застосуванні урокарбу основні показники загального аналізу сечі зали- 
шались на рівні здорових інтактних тварин. Однак відмічали зміщення рівня $\mathrm{pH}$ у слаболужну сторону - до 8,3 одиниці, що є характерним фармакокінетичним параметром для тіадіазольних діуретиків. Профріль іонограми сечі експериментальних тварин при введенні тестованої сполуки характеризувався достовірним збільшенням виділення іонів $\mathrm{Na}^{+}(\mathrm{p} \leq 0,001)$ і статистично недостовірним зменшенням виведення іонів $\mathrm{Cl}^{-} \mathrm{Ta} \mathrm{K}^{+}(\mathrm{p} \leq 0,05)$. Рівень екскреції зазначених електролітів перевищував аналогічні показники в групі інтактного контролю, проте якісно і вигідно вирізнявся щодо рефреренс-препаратів, зокрема нижчим рівнем виведення іонів калію та хлору. LD 50 урокарбу становить 480 мг/кг при внутрішньочеревному способі введення - малотоксична речовина. Гепатотоксичність заявленої сполуки досліджували шляхом оцінки біохімічних параметрів фрункціонального стану печінки: визначали рівні аланін- і аспартатамінотрансфераз, гамма-глутамілтрансферази, загальної лужної фоосфатази, вміст загального білка та загального білірубіну і встановили, що в зразках плазми експериментальних тварин не змінювались активність ензимних систем печінки та рівні ключових метаболітів порівняно 3 інтактними тваринами, що свідчить про відсутність гепатотоксичних проявів при застосуванні урокарбу. Таким чином, зазначені результати вказують на те, що урокарб проявляє високу діуретичну дію та є малотоксичною і негепатотоксичною сполукою. Це передбачає можливість створення на її основі нового діуретичного лікарського засобу.

Мета дослідження - провести експериментальне вивчення валідаційного параметра "лінійність/калібрувальна модель" аналітичної методики кількісного визначення урокарбу в плазмі крові для виконання фармакокінетичних досліджень.

МЕТОДИ ДОСЛІДЖЕННЯ. Об'єктом дослідження був урокарб.

У кожну пробірку вносять по 50 мкл кожного розчину QC-зразків та 50 мкл розчинів кожного внутрішнього стандарту в 450 мкл бланкової плазми. Пробірки закривають та перемішують їх вміст на шейкері протягом 10 с. Вносять 50 мкл розчинів внутрішніх стандартів у 0,5 мл плазми, струшують 4 хв. Осадження білків проводять шляхом додавання 1,5 мл ацетонітрилу та струшування впродовж 4 хв, потім центрифругування при 4000 об./Хв при 5 С проягом 10 Хв. До 1 мл прозорого розчину додають 1 мл води та виконують хроматографрування. Проби хроматографрують 3 використанням хроматографрічної колонки Discovery C18, 50×2,1 мм, 3 розміром часток 5 мкм та градієнтного елюювання. Елюент А - ацетонітрил - вода - кислота мурашина (5:95:0,1), елюент В - ацетонітрил - кислота мурашина (100:0.1). Швидкість потоку 0,4 мл/хв. Температура термостата колонки 30 С. Об'єм проби, яку вводять, -4 мкл.

РЕЗУЛЬТАТИ Й ОБГОВОРЕННЯ. Біоаналітична методика визначення урокарбу ґрунтується на BEPX/MC/MC аналізі аналітів у досліджуваних розчинах, отриманих із зразків плазми після попереднього осадження білків. Придатність біоаналітичної методики була підтверджена валідаційними характеристиками, які висувають до біоаналітичних методик $[7,8]$. У цій роботі описано валідаційний параметр “лінійність/ калібрувальна модель”. Розроблено електронні протоколи з використанням Microsoft Excel, в яких передбачено поля для введення даних.

Лінійність - це здатність аналітичної методики (в певному діапазоні застосування) забезпечувати отримання результатів випробувань, прямо пропорційних концентрації (кількості) аналіту в зразку (ICH). Цей параметр наявний у всіх керівництвах, що дають рекомендації відносно валідації біоаналітичних методик. Лінійність калібрувальної кривої оцінюють за калібрувальними стандартами урокарбу, приготовленими на плазмі крові, використовуючи алгоритм розрахунків параметрів лінійної регресії методом найменших квадратів у системі координат "відношення площ хроматографічних піків аналіту або внутрішнього стандарту до концентрації". Результати вивчення валідаційного параметра "лінійність/калібрувальна модель” аналітичної методики кількісного визначення урокарбу в плазмі крові наведено в таблиці. Калібрувальну криву представлено на рисунку.

При побудові калібрувальної кривої необхідно виконати такі умови: для нижньої межі кількісного визначення відхилення від номінальної концентрації повинно бути не більшим $\pm 20 \%$, для калібрувальних розчинів з концентраціями, вищими, ніж нижня межа кількісного визначення, - не більшим $\pm 15 \%$. Калібрувальні розчини, для яких відхилення становить понад $\pm 15 \%$, слід виключити з розрахунку рівнянь регресії, не змінюючи вихідної моделі.

Згідно з рисунком, доведено лінійну залежність між концентрацією та площею хроматографрічних піків урокарбу в діапазоні концентрацій 1-100 нг/мл. Рівняння регресії $\mathrm{y}=0,00365 \mathrm{x}+0,000177$, коеоріцієнт кореляції $-\mathrm{r}^{2}$ 0,9993. Висновок щодо розробленої методики стосовно валідаційного параметра "лінійність/ калібрувальна модель" - коректна. 
Таблиця - Результати вивчення валідаційного параметра “лінійність/калібрувальна модель" аналітичної методики кількісного визначення урокарбу в плазмі крові

\begin{tabular}{|c|c|c|c|c|c|}
\hline Розчин & $\begin{array}{c}\text { Час } \\
\text { утримування } \\
\text { урокарбу }\end{array}$ & $\begin{array}{c}\text { Члас } \\
\text { урокарбу }\end{array}$ & $\begin{array}{c}\text { Птримування } \\
\text { внутрішнього } \\
\text { стандарту }\end{array}$ & $\begin{array}{c}\text { Площа піка } \\
\text { внутрішнього } \\
\text { стандарту }\end{array}$ & Точність, \% \\
\hline BI & 1,54 & 10 & 1,72 & 56 & N/A \\
\hline Z & 1,56 & 55 & 1,68 & 93415 & N/A \\
\hline C1 & 1,53 & 430 & 1,67 & 100400 & 112,5 \\
\hline C2 & 1,53 & 1059 & 1,67 & 98083 & 96,9 \\
\hline C3 & 1,53 & 3413 & 1,67 & 100360 & 92,6 \\
\hline C4 & 1,53 & 10781 & 1,67 & 98294 & 99,9 \\
\hline C5 & 1,52 & 16675 & 1,66 & 96353 & 94,6 \\
\hline C6 & 1,53 & 27432 & 1,67 & 99699 & 100,4 \\
\hline C7 & 1,53 & 35285 & 1,67 & 93585 & 103,2 \\
\hline Bl & 1,54 & 99 & 1,69 & 78 & N/A \\
\hline Bl & 1,59 & 7 & 1,69 & 135 & N/A \\
\hline
\end{tabular}

Lin CP-DU 060319 4ul.rdb (DU): "Linear" Regression ("1 $/ x "$ weighting): $y=0.00365 x+0.000177(r=0.9993)$

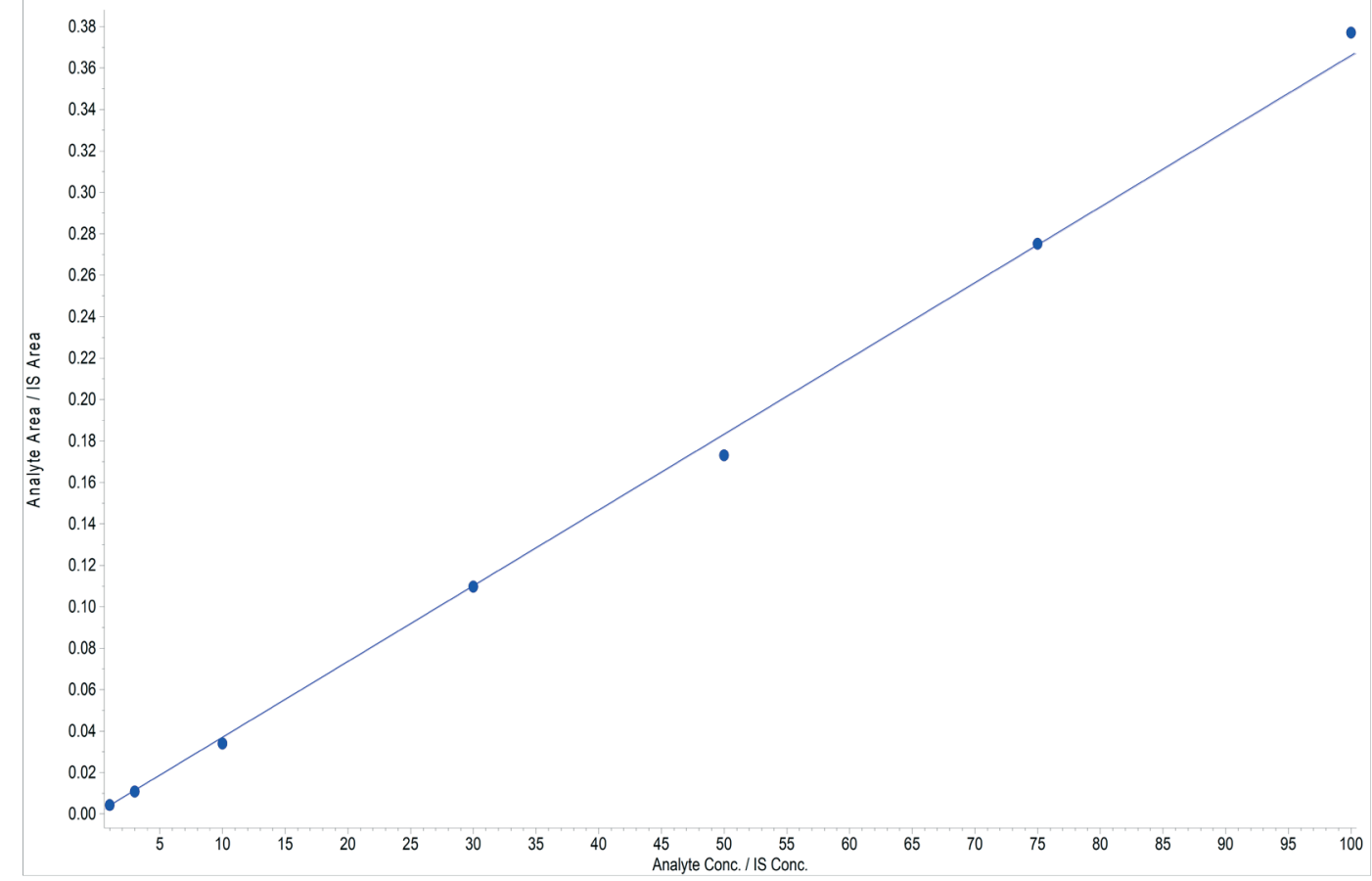

Рис. Калібрувальна крива визначення урокарбу в плазмі крові.

ВИСНОВКИ. 1. Проведено експериментальне вивчення валідаційного параметра "лінійність/калібрувальна модель" аналітичної методики кількісного визначення урокарбу в плазмі

СПИСОК ЛІТЕРАТУРИ

1. ICH Harmonised Tripartite Guideline. Validation of Analytical Procedures: Text and Methodology Q2 (R1). Geneva : ICH, 1995. 13 p. крові для виконання фрармакокінетичних досліджень.

2. Висновок щодо розробленої методики стосовно валідаційного параметра "лінійність/ калібрувальна модель" - коректна.

2. Гризодуб А. И. Стандартизованные процедуры валидации методик контроля качества лекарственных средств / А. И. Гризодуб // Аналитическая химия в 
создании, стандартизации и контроле качества лекарственных средств : в 3 т. / под ред. В.П.Георгиевского. - Харьков : НТМТ, 2011. - Т. 3. - С. 934-1063.

3. Guidance for Industry: Bioanalytical Method Validation / U.S. Department of Health and Human Services, Food and Drug Administration (FDA), Center for Drug Evolution and Research (CDER), Center for Veterinary Medicines (CVM). Washington, DC : U.S. Government Printing Office, 2001. 22 p.

4. Guideline on bioanalytical method validation / European Medicines Agency (EMEA/CHMP/EWP/ 192217/2009). 2011. URL : http://www.ema.europa.eu/ docs/en_GB/document_library/Scientific_guideline/2011/08/WC500109686.pdf.

5. Валидация биоаналитического метода: метод. рек. / ГП “Государственный экспертный центр”. - К., 2013. - 35 c.

6. A strategy for validation of bioanalytical methods / S. Braggio, R. J. Barnaby, P. Grosi, M. Cugola // Journal of Pharmaceutical and Biomedical Analysis. - 1996. - 14, No. 4. - P. 375-388.
7. Singh U. K. Bioanlytical method development and validation / U. K. Singh, P. Pandey, P. K. Keshri // J. Biorg. Chem. - 2000. - 2. - P. 34-45.

8. Causon R. Validation of chromatographic methods in biomedical analysis viewpoint and discussion / R. Causon // J. Chromatogr. B. - 1997. - 689, No. 1. - P. 175180.

9. Sharma A. Bioanalytical method development and validation of drugs in biological fluid / A. Sharma, S. Rathore // Int. J. of Pharm \& Research Sci. - 2012. - 1, No. 4. - P. 216-226.

10. James C. A. Bioanalytical method validation: a risk-based approach / C. A. James, M. Breda, E. Frigerio // Journal of Pharmaceutical and Biomedical Analysis. - 2004. - 35, No. 4. P. 887-889.

11. Bioanalytical method development and validation by using Lc-Ms/Ms / S. Murugan, N. Pravallika, P. Sirisha, K. Chandrakala // Journal of Chemical and Pharmaceutical Sciences. - 2013. - 6, No. 1. - P. 41-45.

12. Драпак I. Синтез, дослідження діуретичної активності та QSAR-аналіз N-(1,3,4-тіадіазол-2-іл) заміщених амідів кислот алканкарбонового ряду / І. Драпак // Фармац. журн. - 2019. - № 2. - С. 55-65.

6. Braggio, S., Barnaby, R.J., Grosi, P., Cugola, M. (1996). A strategy for validation of bioanalytical methods. Journal of Pharmaceutical and Biomedical Analysis, 14 (4), 375-388.

7. Singh, U.K., Pandey, P., \& Keshri, P.K. (2000). Bioanlytical method development and validation. Biorg. Chem., 2, 34-45.

8. Causon, R. (1997). Validation of chromatographic methods in biomedical analysis viewpoint and discussion. J. Chromatogr. B., 689 (1), 175-180.

9. Sharma, A., \& Rathore, S. (2012). Bioanalytical method development and validation of drugs in biological fluid. Int. J. of Pharm \& Research Sci., 1 (4), 216-226.

10. James, C.A., Breda, M. \& Frigerio, E. (2004). Bioanalytical method validation: a risk-based approach. Journal of Pharmaceutical and Biomedical Analysis, 35 (4), 887-889.

11. Murugan, S., Pravallika, N., Sirisha, P., \& Chandrakala, K. (2013). Bioanalytical method development and validation by using LC-MS/MS. Journal of Chemical and Pharmaceutical Sciences, 6 (1), 41-45.

12. Drapak, I. (2019). Syntez, doslidzennia diuretychnoi aktyvnosti ta QSAR-analiz N-(1,3,4-tiadiazol-2-il) zamishchenykh amidiv kyslot alkankarbonovoho riadu [Synthesis, study of diuretic activity and QSAR analysis of N-(1,3,4-thiadiazol-2-yl) substituted amides of acids of the alkanecarboxylic acid series]. Farmatsevtychnyi zhurnal - Pharmaceutical Journal, 2, 55-65 [in Ukrainian]. 


\section{ИЗУЧЕНИЕ ВАЛИДАЦИОННОГО ПАРАМЕТРА “ЛИНЕЙНОСТЬ/ КАЛИБРОВОЧНАЯ МОДЕЛЬ” АНАЛИТИЧЕСКОЙ МЕТОДИКИ КОЛИЧЕСТВЕННОГО ОПРЕДЕЛЕНИЯ УРОКАРБА В ПЛАЗМЕ КРОВИ ДЛЯ ПРОВЕДЕНИЯ ФАРМАКОКИНЕТИЧЕСКИХ ИССЛЕДОВАНИЙ}

\section{Резюме}

Вступление. Анализ публикаций в ведущих мировых химико-аналитических и фрармацевтических журналах позволяет сделать вывод о приоритетном интересе исследователей к валидации биоаналитических методик, на что указывает постоянное изучение валидационных параметров, в том числе параметра "линейность/калибровочная модель". Таким образом, приобретают актуальность вопросы, связанные с определением валидационного параметра “линейность/калибровочная модель", который используют во время доклинических фрармакологических исследований лекарственных средств и разработки стандартизированных подходов к проведению таких валидационных работ для оригинальных субстанций.

Цель исследования - провести экспериментальное изучение валидационного параметра "линейность/калибровочная модель" аналитической методики количественного определения урокарба в плазме крови для выполнения фрармакокинетических исследований.

Методы исследования. Биоаналитическая методика определения урокарба основана на ВЭЖX/MC/ MC анализе аналитов в исследуемых растворах, полученных из образцов плазмы после предварительного осаждения белков. Пробы хроматограсрируют с использованием хроматографрической колонки Discovery С18, 50×2,1 мм, с размером частиц 5 мкм и градиентного элюирования.

Результаты и обсуждение. Пригодность биоаналитической методики была подтверждена валидационными характеристиками, которые предъявляют к биоаналитическим методикам. В этой работе описан валидационный параметр “линейность/калибровочная модель". Разработаны электронные протоколы с использованием Microsoft Excel, в которых предусмотрены поля для ввода данных. При построении калибровочной кривой необходимо выполнить следующие условия: для нижнего предела количественного определения отклонение от номинальной концентрации должно быть не более $\pm 20 \%$, для калибровочных растворов с концентрациями, которые превышают нижний предел количественного определения, - не более \pm 15 \%. Доказана линейная зависимость между концентрацией и площадью хроматографрических пиков урокарба в диапазоне концентраций 1-100 нг/мл. Уравнение регрессии y=0,00365x+0,000177, коэфрфициент корреляции $-r^{2}$ 0,9993.

Выводы. Проведено экспериментальное изучение валидационного параметра "линейность/калибровочная модель" аналитической методики количественного определения урокарба в плазме крови для выполнения фрармакокинетических исследований. Вывод относительно разработанной методики по валидационному параметру “линейность/калибровочная модель" - корректна.

КЛЮЧЕВЫЕ СЛОВА: урокарб; валидация; валидационный параметр “линейность/калибровочная модель"; фрармакокинетика.

I. V. Drapak

DANYLO HALYTSKYI LVIV NATIONAL MEDICAL UNIVERSITY

\section{THE STUDY OF VALIDATION PARAMETER “LINEARITY/CALIBRATION MODEL” OF ANALYTICAL METHODOLOGY OF QUANTITATIVE DETERMINATION OF UROCARB IN BLOOD PLASMA FOR PHARMACOKINETIC STUDIES}

\section{Summary}

Introduction. The analysis of publications in the leading world chemistry-analytical and pharmaceutical journals allows us to conclude that the researchers are of priority interest in the validation of bioanalytical techniques, as evidenced by the constant study of validation parameters, including "linearity/calibration model". Thus, with the definition of the validation parameter "linearity/calibration model" used in preclinical pharmacological research of 
medicinal products and development of standardization their approach to such validation work for the original substance.

The aim of the study - to experimentally learn the validation parameter "linearity/calibration model" for quantitative determination of urocarb in human plasma for pharmacokinetic studies.

Research Methods. The bioanalytical method for the determination of urocarb is based on HPLC/MS/MS analysis of analytes in investigated solutions obtained from plasma samples after pre-precipitation of proteins. Samples were chromatographed using Discovery C18 chromatography column, $50 \times 2.1 \mathrm{~mm}$, with a particle size of $5 \mu \mathrm{m}$ and gradient elution.

Results and Discussion. The suitability of the bioanalytical technique was confirmed by the validation characteristics that are advanced to the bioanalytical methods. In this paper, the validation parameter "linearity/ calibration model" is described. We developed electronic protocols using Microsoft Excel, which provides fields for data entry. When constructing a calibration curve, the following conditions must be fulfilled: for lower limit of quantification (LLOQ), the deviation from the nominal concentration should be no more than $\pm 20 \%$; for calibration solutions with concentrations more than LLOQ, the deviation from the nominal concentration should be no more than $\pm 15 \%$. A linear relationship was found between the concentration and the area of the chromatographic peaks of urocarb in the concentration range of $1 \mathrm{ng} / \mathrm{ml}-100 \mathrm{ng} / \mathrm{ml}$. The regression equation is $y=0.00365 x+0.000177$, the correlation coefficient is $r^{2} 0.9993$.

Conclusions. The study of the validation parameter "linearity/calibration model" of analytical method of quantitative determination of urocarb in plasma is conducted for pharmacokinetic studies. The conclusion on the developed methodology according to the validation parameter "linearity/calibration model" is correct.

KEY WORDS: urocarb; validation; “linearity/calibration model”; pharmacokinetics.

Отримано 10.04.19

Адреса для листування: І. В. Драпак, Львівський національний медичний університет імені Данила Галицького, вул. Пекарська, 69, Львів, 79010, Україна, e-mail: iradrapak@ukr.net. 